\title{
EFEKTIVITAS SENAM AEROBIC TERHADAP KADAR GULA DARAH PREDIABETES KELOMPOK IBU-IBU SENAM DI GOR UNAI KECAMATAN PARONGPONG KABUPATEN BANDUNG BARAT
}

\author{
EFFECTIVENESS OF AEROBIC GYMNASTIC ON BLOOD SUGAR \\ LEVEL PRE-DIABETES OF WOMAN GROUP IN GOR UNAI \\ PARONGPONG BANDUNG BARAT DISTRICTS
}

Imanuel Sri Mei Wulandari ${ }^{1}$, Venessa Putri Amalia ${ }^{2}$

Fakultas IImu Keperawatan, Universitas Advent Indonesia

Email: hutabarat.venessa@yahoo.co.id

\begin{abstract}
ABSTRAK
Penelitian ini di latar belakangi oleh prevalensi DMT2 di daerah perkotaan Indonesia yaitu $5,7 \%$ sedangkan prevalensi pre-diabetes hampir dua kali lipatnya yaitu $10,2 \%$. Kebanyakan masyarakat Indonesia memilih untuk memeriksakan dirinya ketika sudah mengalami penyakit DMT2 terlebih dahulu, dibandingkan dengan mencegahnya. Pre-diabetes dapat dicegah dengan berbagai cara, salah satunya dengan cara berolahraga. Olahraga yang digunakan yaitu olahraga senam aerobic yang dapat dibilang murah dan dapat diikuti oleh semua generasi. Peneliti ingin mengetahui apakah ada perbedaan pada kadar gula darah sebelum dan sesudah setelah diberikan senam aerobic. Desain metode penelitian menggunakan perlakuan berulang (One Group Pretest-Posttest Design). Peneliti akan melakukan pengecekan kadar gula darah puasa sebelum dilakukan senam aerobic dan setelah melakukan senam aerobic, responden akan dicek kembali kadar gula darah puasa. Populasi yang digunakan 35 ibu-ibu yang selalu mengikuti senam aerobic selama 3 kali seminggu dan sampel yang digunakan berjumlah 9 responden. Sampel dipilih menggunakan teknik total sampling. Hasil yang didapatkan setelah penelitian selama 3 kali seminggu, dengan menggunakan rumus mean dan paired t test, didapatkan bahwa hasil rata-rata kadar gula darah puasa sebelum diberikan intervensi adalah 106,56 dan hasil rata-rata kadar gula darah puasa sesudah diberikan intervensi adalah 107,44. Hasil thitung yang didapatkan adalah 0,206 lebih kecil dibandingkan ttabel yaitu 1,860 dan dapat ditarik kesimpulan bahwa Ho diterima (tidak ada perbedaan sebelum dan sesudah dilakukan senam aerobic. Bisa terjadi kenaikan akibat responden sebelum puasa mengkonsumsi makanan yang membuat gula darah menjadi naik. Saran kepada peneliti selanjutnya melanjutkan penelitian ini dengan populasi yang lebih banyak dan melakukan penelitian lebih lama dari penelitian sebelumnya.
\end{abstract}

Kata kunci: Senam aerobic, kadar gula darah, pre-diabetes

\section{ABSTRACT}

This study was based on the prevalence of DMT2 in urban areas of Indonesia that is $5.7 \%$ while the prevalence of pre-diabetes is almost twice that of $10.2 \%$ (Riskesdas, 2007). Indonesian people choose to check themselves when they have DMT2 first, compared to preventing it. Pre-diabetes can be prevented in many ways, one of them by way of exercise. Sport that is used is aerobic gymnastics, aerobic gymnastics is a sport that can be practically cheap and can be followed by all generations. Therefore, researchers want to know there is a difference in blood sugar levels before and after after given aerobic exercise. The research method design uses repetitive treatment (One Group PretestPosttest Design). Researchers will check the fasting blood sugar levels before aerobic exercise and after doing aerobic exercise, respondents will be checked again fasting blood sugar levels. The population used 35-woman group who always follow aerobic gymnastics for 3 times a week and the sample used amounted to 9 respondents. The sample was selected using total sampling 
technique. Results obtained after 3 weeks of research, using the mean and paired $t$ test, found that the mean fasting blood sugar level before intervention was 106,56 and the mean result of fasting blood sugar after intervention was 107,44 . The result of tcount obtained is 0,206 smaller than ttable that is 1,860 and can be drawn conclusion that $\mathrm{HO}$ accepted (no difference before and after done aerobic gymnastics. There could be an increase due to the respondents before fasting to consume foods that make blood sugar to rise.

Suggestions to the researchers then continued this study with more populations and carried out longer studies than previous studies.

Key words: Aerobic gymnastic, blood sugar levels, pre-diabetes

\section{PENDAHULUAN}

Menurut Riset Kesehatan Dasar (Riskesdas, 2010) menunjukkan bahwa prevalensi DMT2 di daerah perkotaan Indonesia adalah $5,7 \%$ sedangkan prevalensi pre-diabetes hampir dua kali lipatnya yaitu 10,2\%. Dengan meningkatnya prevalensi DMT2, maka prevalensi pre-diabetes pun akan ikut meningkat lebih tinggi, karena jumlah individu yang belum terdeteksi DMT2 (termasuk prediabetes) lebih banyak dibanding DMT2.

Kebanyakan masyarakat Indonesia kurang mengetahui bahwa dirinya terkena penyakit diabetes dan memilih untuk memeriksa kesehatan dikala mereka sudah terkena penyakit di stadium akhir, yang memungkin untuk tidak bisa di sembuhkan kembali.

Seseorang akan dikatakan terkena penyakit pre-diabetes ketika kadar gula darah puasa antara $100 \mathrm{mg} / \mathrm{dl}$ $125 \mathrm{mg} / \mathrm{dl}$ atau kadar gula darah dua jam setelah makan lebih besar dari $140 \mathrm{mg} / \mathrm{dl}$ - $200 \mathrm{mg} / \mathrm{dl}$. Pre-diabetes dapat ditandai juga dengan obesitas, di dalam keluarga memiliki riwayat diabetes, umur diatas 45 tahun, pola hidup di masa lalu yang tidak baik, tekanan darah yang tinggi, dan memiliki riwayat diabetes gestational untuk wanita (Setiawan, 2011).

\section{TUJUAN PENELITIAN}

Untuk mengetahui apakah ada pengaruh yang terjadi dari intervensi senam aerobic terhadap kadar gula darah bagi penderita pre-diabetes.

Untuk membantu masyarakat mengetahui manfaat senam aerobic terhadap kadar gula darah.

\section{MANFAAT PENELITIAN}

Hasil penelitian ini diharapkan dapat menjadi penambahan pengetahuan bagi para pembaca dan perawat, dan dapat menggunakan senam aerobic ini sebagai intervensi pencegahan terjadinya DMT2.

\section{BAHAN DAN METODE}

Desain penelitian yang digunakan yaitu teknik Kuantitatif dengan Desain Praeksperimen yang menggunakan bentuk desain perlakuan berulang (One Group Pretest-Posttest Design) yang menggunakan satu kelompok subjek serta melakukan pengukuran sebelum dan sesudah perlakuan (pretest (O1) dan posttest (O2).

Populasi yang peneliti gunakan yaitu 35 ibu-ibu yang selalu mengikuti senam aerobic selama 3 kali seminggu 
di GOR UNAI. Sampel yang akan digunakan peneliti berjumlah 13 responden. Sampel dipilih dengan menggunakan teknik Total Sampling.

\section{HASIL PENELITIAN}

Hasil penelitian ini diperoleh dari 9 orang sampel yang telah diukur kadar gula darahnya sebelum dan sesudah dilakukan senam aerobic di GOR UNAI. Data yang dikumpulkan diolah menggunakan SPSS dan

Excel.

Tabel 1. Hasil Pengukuran Kadar Gula Darah Sebelum Senam Aerobic

\begin{tabular}{|c|c|}
\hline No & $\begin{array}{c}\text { Kadar Gula } \\
\text { Darah PreTest }\end{array}$ \\
\hline 1 & 100 \\
\hline 2 & 99 \\
\hline 3 & 99 \\
\hline 4 & 119 \\
\hline 5 & 100 \\
\hline 6 & 101 \\
\hline 7 & 125 \\
\hline 8 & 113 \\
\hline 5 & 103 \\
\hline Mean & $\bar{X}: \frac{959}{9} \quad \begin{array}{c}\text { Hasil: } \\
\text { I06,56 }\end{array}$ \\
\hline
\end{tabular}

Presentase di atas dari 9 responden memiliki mean adalah 106,56 yang masuk dalam kategori pre-diabetes, dengan standar deviasi yang didapat dari SPSS v.22 yaitu 9,876.

Tabel 2. Hasil Pengukuran Kadar Gula Darah Sesudah Senam Aerobic

\begin{tabular}{|c|c|}
\hline No & $\begin{array}{c}\text { Kadar Gula } \\
\text { Darah PostTest }\end{array}$ \\
\hline 1 & 112 \\
\hline 2 & 99 \\
\hline 3 & 93 \\
\hline 4 & 119 \\
\hline 5 & 125 \\
\hline 6 & 91 \\
\hline 7 & 105 \\
\hline 8 & 120 \\
\hline 9 & 103 \\
\hline Mean & $\bar{X}: \frac{967}{9}$ \\
& Hasil:107,44 \\
\hline
\end{tabular}

Dari tabel diatas dapat diketahui bahwa rata-rata kadar gula darah sesudah diberikan intervensi yaitu 107,44 dengan jumlah pasien sebanyak 9 orang, yang menyatakan masih memasuki kategori prediabetes.

Tabel 3. Hasil Uji Paired T-Test

\begin{tabular}{|c|c|c|}
\hline $\mathrm{t}$ & $\mathrm{df}$ & Sig.(2tailed) \\
\hline 0,206 & 8 & 0,842 \\
\hline
\end{tabular}

Bila thitung $<$ tabel maka $\mathrm{H}_{0}$ akan diterima, sedangkan bila $t_{\text {hitung }}>t_{\text {tabel }}$ maka $\mathrm{H}_{\mathrm{a}}$ yang diterima. Dimana $\mathrm{t}_{\text {tabel }}$ dicari dari tabel distribusi "+". ttabel diperoleh dengan menetapkan tingkat signifikan (a) dan derajat kebebasan (df). Nilai signifikasi yang diperoleh adalah 0,842>0,05. Maka kesimpulan yang dinyatakan adalah hasil yang didapati tidak signifikan. Sehingga dapat disimpulkan bahwa senam aerobic tidak mempunyai perubahan yang signifikan, namun kadar gula darahnya masih tetap stabil.

\section{PEMBAHASAN}

Penelitian ini merupakan penelitian pra-eksperimental yang bertujuan untuk mengetahui apakah ada perbedaan kadar gula darah sebelum dan sesudah setelah diberikan intervensi yaitu senam aerobic pada penderita pre-diabetes. Melakukan penelitian ini merupakan suatu proses untuk mengetahui apakah senam aerobic dapat dijadikan sebagai intervensi untuk penurunan kadar gula darah kepada para penderita prediabetes. Dari analisis data yang diperoleh maka dapat diketahui bahwa pada saat pemeriksaan kadar gula darah puasa sebelum diberikan 
intervensi adalah 106,56 yang masuk dalam kategori pre-diabetes. Dan setelah diberikan intervensi dan dicek kembali kadar gula darah puasa yang rata-ratanya adalah 107,44 yang berarti terjadi kenaikan rata-rata pada gula darah tersebut yang masih tergolong dalam kategori prediabetes.

Senam aerobic merupakan aktivitas fisik yang sering dilakukan oleh kalangan masyarakat dan memerlukan banyak oksigen untuk membantu otototot dalam tubuh bergerak (Mulyono, 2013). Senam aerobic merupakan suatu proses yang sistematis dengan menggunakan rangsangan gerak yang bertujuan untuk meningkatkan atau mempertahankan kualitas fungsional tubuh yang meliputi kualitas daya tahan paru-jantungm kekuatan dan daya tahan otot, kelenturan dan komposisi tubuh (Irianto, 2000). Senam aerobic dapat meningkatkan daya tahan tubuh.

Oksigen juga sangat dibutuhkan oleh otot untuk membantu mencegah terkenanya penyakit asam laktat, pembuluh darah kita akan menyediakan oksigen yang cukup dalam otot. Oksigen sangat memegang peranan penting di dalam tubuh kita. Oksigen dibutuhkan saat kita sedang melakukan aktivitas maupun tidak melakukan aktivitas. Untuk mendapatkan energi selain berasal dari glukosa, tubuh kita membutuhkan oksigen sebagai bahan bakar. Reaksi kimia antara gula dan oksigen akan menghasilkan Adenosine Tri Phosphate (ATP) yang disebut sebagai energi murni sel. Kekurangan oksigen akan menurunkan cadangan energi tubuh. Tubuh akan merasa mudah capek. Selain itu, kekurangan ATP akan mengganggu sinyal elektis dari otak ke otot sehingga membuat otot lelah. Jika tubuh kita kekurangan oksigen dalam waktu tertentu, sel tubuh kita akan mengalami kerusakan yang menetap dan menimbulkan kematian (Sugiyono, 2012). Saat tubuh mengalami kekurangan oksigen, yang akan terjadi banyak sel-sel tubuh akan rusak dan yang akan paling parah terjadi yaitu kematian. Kekurangan oksigen juga dapat memicu terjadinya kanker, selain dari kanker juga dapat menurunkan berat badan akibat dari kurangnya nafsu makan.

Adapun penelitian yang dilakukan oleh Indra (2000), menggunakan terapi oksigen hiperbarik pada pasien diabetes. Terapi okesigen hiperbarik adalah terapi dimana pasien ditempatkan dalam suatu tabung dengan tekanan 2,4 ATA dan menghirup oksigen murni $100 \%$ (Sahni, 2003). Dalam penelitian ini didapatkan hasil yaitu terjadi penurunan kadar glukosa darah dan HbA1c akibat efek oksigen bertekanan tinggi. Terapi oksigen hiperbarik meningkatkan sensitivitas jaringan terhadap insulin dan menimbulkan hipoglikemik pada penderita diabetes, dimana terapi oksigen hiperbarik pada 2,4 atmosfer absolut menimbulkan penurunan kadar gula darah (Ishihara, 2007). Pada penderita diabetes terjadi penurunan sensitivitas di sel Langerhans yang menyebabkan gula darah tidak terkontrol, dengan adanya peningkatan suplai $\mathrm{O} 2$ mengakibatkan perbaikan metabolisme pada sel Langerhans yang sekaligus meningkatkan sensitivitas sel Langerhans dalam merangsang pengeluaran insulin untuk mengontrol kadar gula darah (Indra, 2000). 
Adapun pengaruhnya terhadap penurunan kadar gula darah yaitu pada otot-otot yang aktif bergerak tidak diperlukan insulin untuk memasukan glukosa kedalam sel karena pada otot yang aktif sensitifitas reseptor insulin menjadi meningkat sehingga ambilan glukosa meningkat 7 - 20 kali lipat. Menurut Asdie (1997), mekanisme regulasi ambilan glukosa oleh otot pada waktu aktif bergerak disebabkan oleh:

1. Insulin memacu pelepasan muscle activating factor (MAF) pada otot yang sedang bergerak, sehingga menyebabkan ambilan glukosa oleh otot tersebut menjadi bertambah dan ambilan glukosa oleh otot yang tidak berkontraksipun ikut meningkat. Saat ini MAF diduga bradikinin.

2. Adanya aksi lokal hormon pada anggota badan yang sedang bergerak yang disebut non supresible insulin like activity (NSILA) yang terdapat pada aliran limfe dan tidak dalam darah anggota badan tersebut.

3. Adanya peningkatan penyediaan glukosa dan insulin, karena adanya peningkatan aliran darah kedaerah otot yang aktif bergerak

4. Adanya hipoksia lokal yang merupakan stimulus kuat untuk ambilan glukosa

5. Adanya interaksi proses metabolik, dimana bila glikogenolisis meningkat maka pembakaran glukosa menurun, karena glukosa 6 fosfat menghambat enzim hexokinase, disamping peningkatan oksidasi asam lemak bebas.

Peneltian yang dilakukan oleh Puji I (2007) dalam jurnalnya yang meneliti pengaruh senam aerobic terhadap penurunan kadar gula darah penderita
DM tipe 2 mengatakan bahwa penurunan yang terjadi bukanlah hasil yang mutlak karena para responden menggunakan obat hipoglikemi oral $(\mathrm{OHO})$ dan menjalani diet DM. Menurut

Sjaifoellah Noer (1996) mengatakan dengan menggunakan $\mathrm{OHO}$, dapat menurunkan kadar glukosa darah puasa mencapai $36 \%$ - $21 \%$ dan menurut Soegondo (2002), dengan menjalankan diet DM yang teratur dapat berpengaruh terhadap penurunan kadar gula darah sebesar $3 \%$.

Maka dari hasil penelitian dan saat dibandingkan dengan teori dan penelitian yang ada, untuk penderita pre-diabetes tidak memiliki pengaruh yang signifikan terhadap penurunan kadar gula darah puasa. Karena, bisa saja terjadi kenaikan akibat dari para responden sebelum puasa mengkonsumsi makanan yang membuat gula darah menjadi naik. Kenaikan gula darah juga dapat terjadi akibat para responden tidak maksimal dalam melakukan gerakan senam aerobic yang di contohkan oleh instruktur.

\section{KESIMPULAN}

Kesimpulan yang diperoleh dari penelitian yang telah dilakukan dan uji statistik yang digunakan dalam penelitian ini adalah:

1) Hasil nilai rata-rata kadar gula darah puasa sebelum diberikan senam aerobic adalah 106,56 dengan kategori termasuk prediabetes.

2) Hasil rata-rata kadar gula darah puasa setelah diberikan senam aerobic adalah 107,44 dengan kategori termasuk pre-diabetes. 
3) Terdapat perbedaan hasil rata-rata yang menyimpulkan terjadi kenaikan terhadap kadar gula darah puasa sebelum dan sesudah diberikan senam aerobic.

\section{DAFTAR PUSTAKA}

Asdie,S.H. 1997. Latihan Jasmani Sebagai Terapi Pada Diabetes Mellitus in Soeparman Ilmu Penyakit Dalam. Jakarta.

Irianto,D.P. 2000. Panduan Latihan Kebugaran Fisik (yang Efektif dan Aman). Yogyakarta: Lukman Offset

Isihira, A. 2007.Hyperbarik Exposure in Rat Muscle and Nerve Laboratory of Metabolism. Graduate School of Human Genomic Drug Discovery Science.

Kyoko University: Japan.

Mulyono, J. (2013). Senam Aerobik. Jakarta: EGC.

Puji I., H. S. (2007). Pengaruh Latihan Fisik; Senam Aerobik Terhadap Penurunan Kadar Gula Darah Pada Penderita DM Tipe 2 Di Wilayah Puskesmas Bukateja Purbalingga. Media Ners, 4999.

Riskesdas. (2010). Situasi dan Analisis Diabetes. Dipetik 2014, dari depkes:http://www.searo.who .int/indonesia/topics/8 whd2016-diabetes-facts-and numbers-indonesian.pdf

Setiawan, M. (2011). Pre-Diabetes dan Peran HbA1c dalam Skrining dan Diagnosis Awal
Diabetes Melitus. Jurnal Bidang Kedokteran dan Kesehatan Universitas Muhammadiyah Malang, 17(14).

Sjaifoellah Noer. 1996. Buku Ajar Ilmu Penyakit Dalam. Jilid 1 Edisi 3. Jakarta: FKUI. 593647

Sugiyono. 2012. Manfaat Oksigen

Dan Dampak Dari

Kekurangan Oksigen. . 